\title{
Treatment of Synthetic Dairy Wastewater Using Disposed Plastic Materials as Trickling Filter Media: Optimization and Statistical Analysis by RSM
}

\author{
Shuokr Qarani Azizi, ${ }^{*}$ and Sazan Mohammed Ali² \\ ${ }^{1}$ Department of Civil Engineering, College of Engineering, Salahaddin University-Erbil, Iraq; \\ ${ }^{2}$ Department of Dams and Water Resources Engineering, College of Engineering, Salahaddin University -Erbil, Iraq
}

Correspondence Author: Shuokr Qarani Aziz, Department of Civil Engineering, College of Engineering, Salahaddin University-Erbil, Iraq; Email: shoker71@yahoo.com

Received date: 20 August 2019, Accepted date: 01 October 2019, Online date: 30 October 2019

Copyright: (C) 2019 Shuokr Qarani Aziz and Sazan Mohammed Ali., This is an open-access article distributed under the terms of the Creative Commons Attribution License, which permits unrestricted use, distribution, and reproduction in any medium, provided the original author and source are credited.

\begin{abstract}
This work was aimed to study the treatment of synthetic dairy wastewater by using the biological trickling filter technique. Synthetic dairy wastewater was prepared in the laboratory by using an organic source of commercially powdered starch. Experiments were designed, conducted, and results were analyzed by using response surface methodology (RSM). The variables were filter media depth, size, and types such as river rocks, disposed plastic caps, and parts of polyvinyl chloride pipe. The responses were chemical oxygen demand (COD), electrical conductivity (EC), turbidity, and colour. Optimum results obtained by RSM for the disposed plastic cap filter media with medium size of $5 \mathrm{~cm}$ and $60 \mathrm{~cm}$ depth were chosen as optimum conditions. The optimum removal values of COD, EC, turbidity, and colour for disposed plastic cap media were

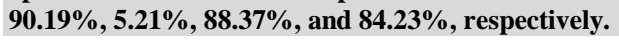

Keywords: Dairy wastewater, synthetic, biological treatment, trickling filter, response surface methodology

\section{INTRODUCTION}

The dairy industry is generally considered the largest source of food processing wastewater in many countries because it consumes large amounts of water for each ton of products and is characterized by a multitude of products such as milk, butter, cheese, yoghurt, and whey. The dairy industry generates roughly $0.2-10 \mathrm{~L}$ of effluent per $\mathrm{L}$ of processed milk. Therefore, the effluents create a large volume of wastewater and cause problems and challenges to the environment [1-3].

Yoruksut dairy factory (YDF) is one of the Turkish dairy factories established in Erbil City, Iraq. YDF produces approximately 40-50 tons of yoghurt and buttermilk per day [4]. Given the absence of wastewater treatment plants in YDF, the produced wastewater is directly discharged to the natural environment. Biological trickling filter (BTF) is one of the attached growth processes that are used for municipal and industrial wastewater treatment. In a BTF system, the microorganisms in wastewater consume organic materials to form a biological layer called slime (biofilm) layer around the surface of filter media [5]. The formation and growth of a biofilm layer on the surface of filter media are complicated processes in biological filtration; the strength of the attachment of microorganisms depends on environmental conditions, surface media properties, types of microorganisms, and fluid characteristics [5-7].

Many studies were conducted on the performance of BTF under different filter packing media. The main goal of media to achieve high removal of pollutant. Thus, a study was performed on multimedia filters (Aerocon stone, brickbats, and plastic scrubber) using upflow and downflow filtration to treat domestic wastewater. Removal efficiencies for five-day biochemical oxygen demand $\left(\mathrm{BOD}_{5}\right)$, chemical oxygen demand $(\mathrm{COD})$, and total solids were $58.54 \%, 52.15 \%$, and $82.31 \%$, respectively [8]. Shahriari and Shokouhi [9] studied BTF with lava rock filter media for the treatment of dairy wastewater and obtained a removal efficiency for COD of more than $85 \%$.

Improving the performance of the systems and increasing the yield of the processes without increasing the cost through optimization is essential. In this study, central composite design (CCD) response surface methodology (RSM) were applied for the design of experiments, statistical analysis, and optimization of BTF independent variables. RSM collects mathematical and 
statistical methods that are beneficial for the modelling and analysis of problems, in which a response of interest is affected by some parameters; additionally, the purpose is to optimize this response [10]. The variables were filtering media depth and size for different types of media, such as river rocks, disposed plastic caps, and parts of polyvinyl chloride (PVC) pipe. The responses were COD, electrical conductivity (EC), turbidity, and colour. Responses such as COD, EC, turbidity, and colour are essential, because COD related to organic matters, EC measures total soluble salts, turbidity and colour are associated to presence of suspended and dissolved solids in wastewater. So, removal of COD, EC, turbidity and color from wastewater are significant. Disposal of plastic caps and PVC pipes increases the amount of generated solid waste and causes environmental problems. Thus, the main objective of this study was to protect the environment from pollution by reusing disposed plastic caps and pieces of PVC pipes as filter media in BTFs. The aims of the work were to (1) study characteristics of dairy wastewater and preparation of synthetic wastewater, and (2) examine depth, size and types of filter media such as river rocks, disposed plastic caps and pieces of PVC pipes for removal of COD, EC, turbidity and colour in BTFs. Few studies have been conducted on the performance of BTF with different disposable materials as filter media with different sizes and depths.

\subsection{Synthetic Dairy Wastewater}

\section{MATERIALS AND METHODS}

COD characteristics for YDF wastewater during January 2016, March 2016, and May 2016 were $1132 \mathrm{mg} / \mathrm{L}, 951 \mathrm{mg} / \mathrm{L}$, and $1030 \mathrm{mg} / \mathrm{L}$, respectively. In this research, the authors examined the effect of variables (filter media depth and size) on the responses (COD, EC, turbidity, and colour) in different BTFs. Researchers reported that the environment and seasons have a noticeable effect on the characteristics of wastewaters [11-12]. To avoid the effect of wastewater quality variation on the research variables, synthetic dairy wastewater in the laboratory was prepared and used in the experiments. Based on the actual concentration of COD value for YDF wastewater, synthetic dairy wastewater was prepared daily. Synthetic dairy wastewater was prepared in the laboratory throughout this study by using an organic source of commercially powdered starch; its primary ingredient of cornstarch has a fine light texture and is mixed with tap water to simulate the same COD of wastewater from the dairy factory. Consequently, different starch dosages of $0.1,0.3,0.5,1,2,3$, and $4 \mathrm{~g} / \mathrm{L}$ were used. An approximate $1: 1$ ratio is expected between starch and COD. The amount of added starch was $1 \mathrm{~g} / \mathrm{L}$ to verify the actual and typical COD concentration of approximately $1000 \mathrm{mg} / \mathrm{L}(950 \pm 50 \mathrm{mg} / \mathrm{L})$.

\subsection{Pilot Plant}

\subsubsection{Experimental Setup}

The pilot scales of BTF were constructed in the laboratory. The BTF system consists of a feed tank with a capacity of 1000 L for the storage of synthetic dairy wastewater, Figure 1. At the top of the tank, an electric mixer with 180-700 rpm rotation speed and $850 \mathrm{~mm}$ shaft length were connected for adequate mixing of the wastewater every $2 \mathrm{~h}$. The synthetic dairy wastewater was prepared daily inside a large bucket with a working volume of $70 \mathrm{~L}$. Then, the wastewater was pumped to the feed tank by using a water pump, stored in the tank, and then discharged by gravity into six identical transparent plastic columns each representing a BTF, Figure 1. BTF columns were built $30 \mathrm{~cm}$ apart, each with an internal diameter of $15 \mathrm{~cm}$ and a total height of $100 \mathrm{~cm}$. The BTF columns were built to maintain and operate different filter media types and sizes at the same time. A flow distributor system was installed at the top of the filters by using plastic pipes and small water sprayers to facilitate uniform distribution of the wastewater fed to the filter's free surface. Each water sprayer was connected with a control valve to control the flow rate of the wastewater by using a flow meter with a capacity of $1 \mathrm{~L} / \mathrm{min}$. The flow rate of the filters was checked every day with the flow meter device to ensure that the filters operated under the required flow rate.

The head above the filters was approximately $1 \mathrm{~m}$ from the beneath of the tank to the top of the BTF columns. At the bottom of each BTF columns, a control valve was installed for taking effluent samples.

In the current research, different types of packing media were used such as, river, plastic caps, and PVC pipes with properties as shown in Table 1. 


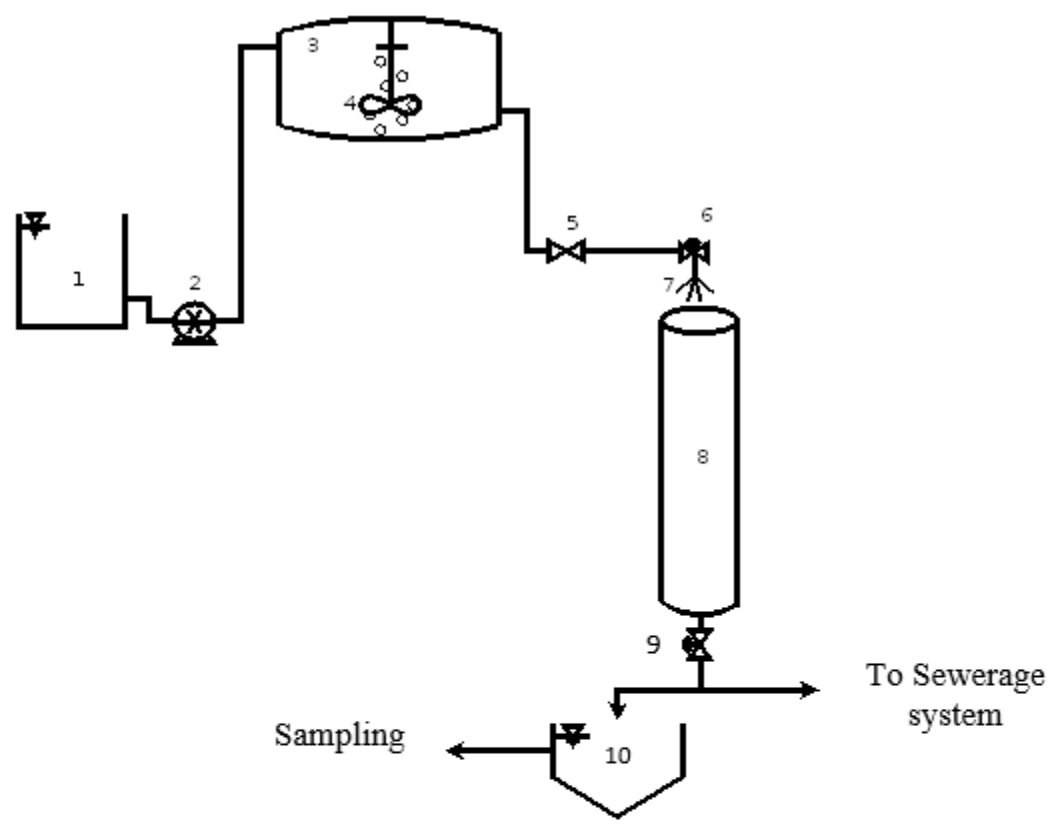

1: Synthetic wastewater
2: Water pump
3: Wastewater storage Tank
4: Electric mixer
5: Horizontal aligned control valve
6: Control valve
7: Wastewater sprayer
8: BTF filled with media
9: Vertical aligned control valve
10: Sample collector

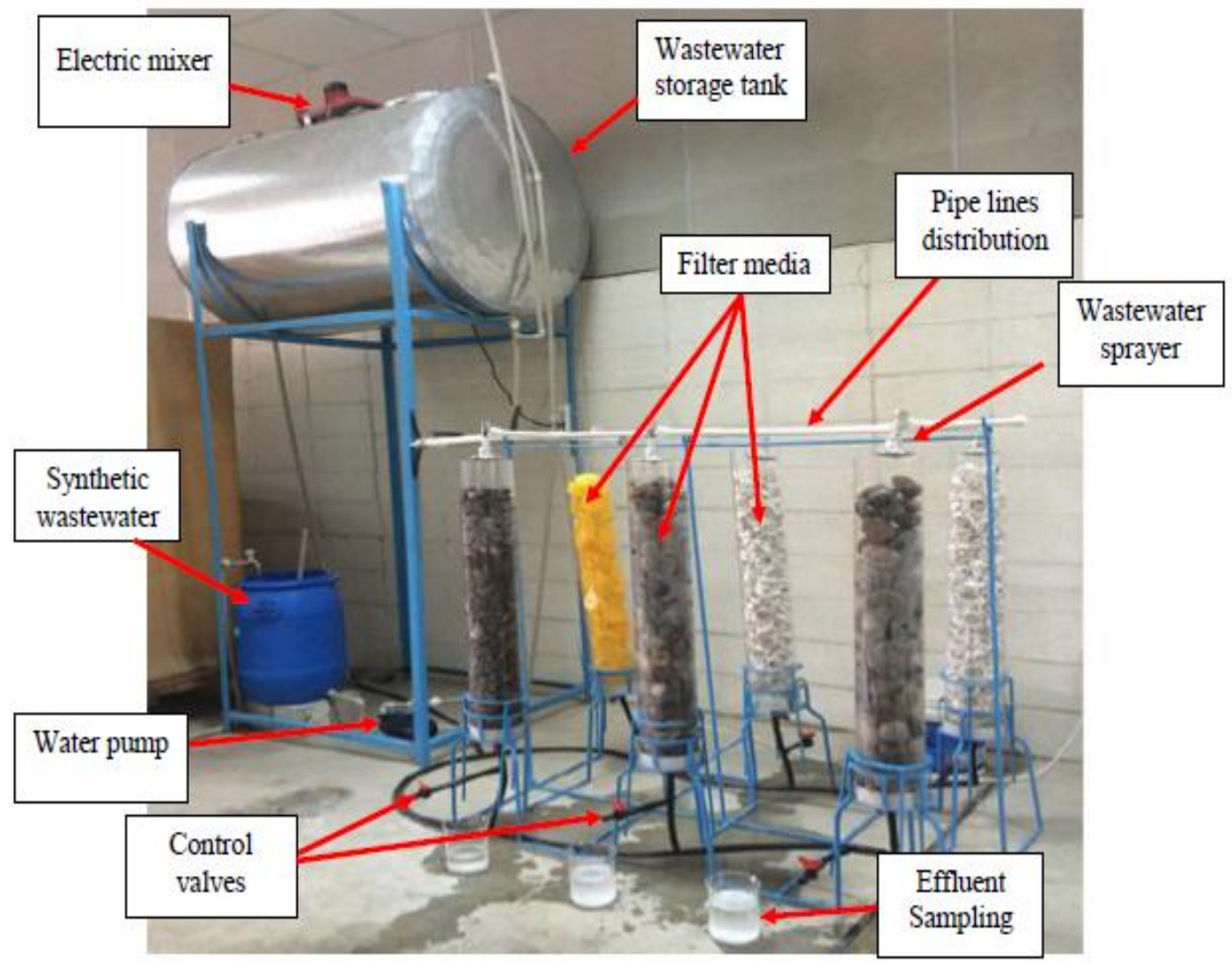

Figure 1: Details of the pilot plant 
Table 1: Details of the properties of used filter media

\begin{tabular}{|c|c|c|c|c|c|c|}
\hline $\begin{array}{l}\text { Filter } \\
\text { media }\end{array}$ & Diameter $(\mathrm{cm})$ & $\begin{array}{l}\text { Length } \\
(\mathrm{cm})\end{array}$ & Surface area $\left(\mathrm{cm}^{2}\right)$ & $\begin{array}{l}\text { Volume } \\
\left(\mathrm{cm}^{3}\right)\end{array}$ & $\operatorname{SSA}\left(\mathrm{m}^{2} / \mathrm{m}^{3}\right)$ & $\begin{array}{l}\text { Void ratio } \\
(\%)\end{array}$ \\
\hline \multicolumn{7}{|c|}{ River Rocks } \\
\hline Small & $1.95-3.0$ & - & 11.0034 & 3.432 & 320.611 & 34 \\
\hline Medium & $3.0-5.0$ & - & 56.326 & 39.75 & 141.700 & 36 \\
\hline Large & $5.0-9.0$ & - & 162.77 & 195.283 & 83.350 & 37.5 \\
\hline \multicolumn{7}{|c|}{ Disposed plastic caps } \\
\hline Small & 3.1 & 0.8 & 34.5 & 0.936 & 3685.897 & 85 \\
\hline Medium & 3.2 & 1.7 & 54.38 & 1.624 & 3348.522 & 86 \\
\hline Large & 7.5 & 1.75 & 167.65 & 12.12 & 1383.250 & 89 \\
\hline \multicolumn{7}{|c|}{ Disposed PVC pipe parts } \\
\hline Small & 3.33 & 1.5 & 33.86 & 3.62 & 935.359 & 86 \\
\hline Medium & 5 & 1.5 & 52.228 & 5.95 & 877.781 & 91 \\
\hline Large & 8.81 & 3 & 169.83 & 8.614 & 1971.557 & 92.5 \\
\hline
\end{tabular}

\subsection{Adaptation Phase of BTF Columns}

In this phase, the startup operation of rock BTFs (small, medium, and large) with a depth of $90 \mathrm{~cm}$ of filter media columns were initially acclimated. The columns were continuously fed with synthetic dairy wastewater at a flow rate of $0.1 \mathrm{~L} / \mathrm{min}$ over 7 days. The influent concentration and removal efficiency of turbidity were calculated every day. Initially, the rock BTFs were adapted alone as a control BTF system. Afterwards, the other filter media types were adapted in the same manner based on the adaptation time obtained from rock BTFs. The acclimation phase for filters was conducted prior to the RSM experiments. The results of the adaptation phases for all type of BTFs are shown in Figures 2, 3, and 4. Evidently, for all BTF types, the filters operated steadily for $7 \mathrm{~d}$, thereby indicating that sudden changes or fluctuations in the results did not occur. Thus, an adaptation time of one week was selected for all BTFs because the results reached a steady-state condition and a yellowish thin layer of biofilm was observed on the filter media.

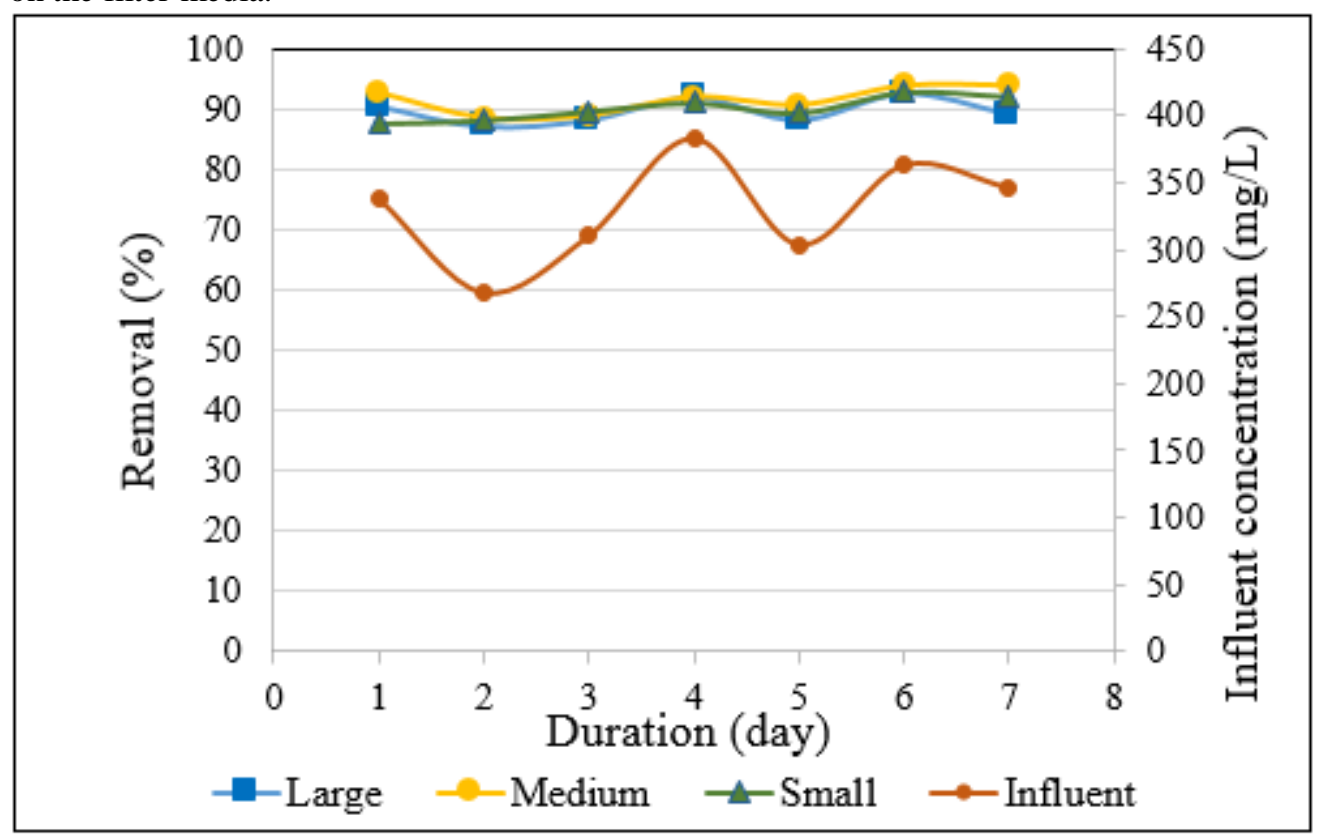

Figure 2: Turbidity removal efficiency for rock BTFs in adaptation phase 


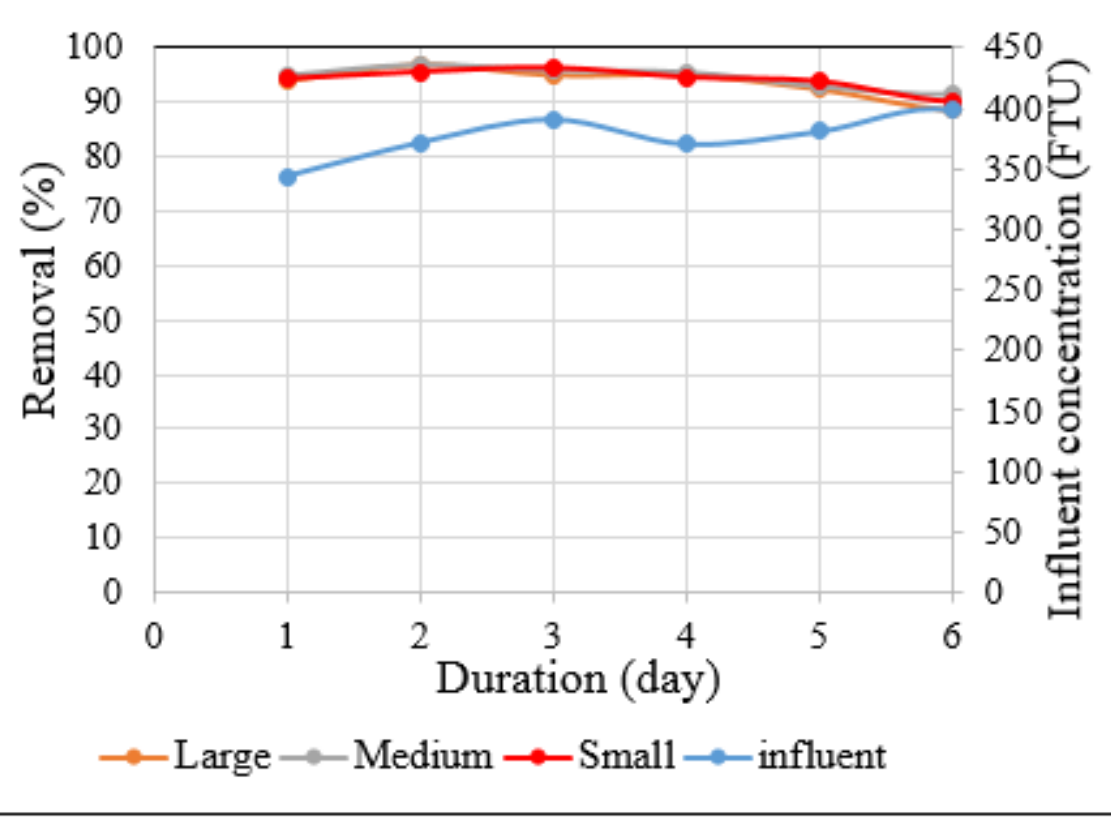

Figure 3: Turbidity removal efficiency for disposed plastic caps BTFs in adaptation phase

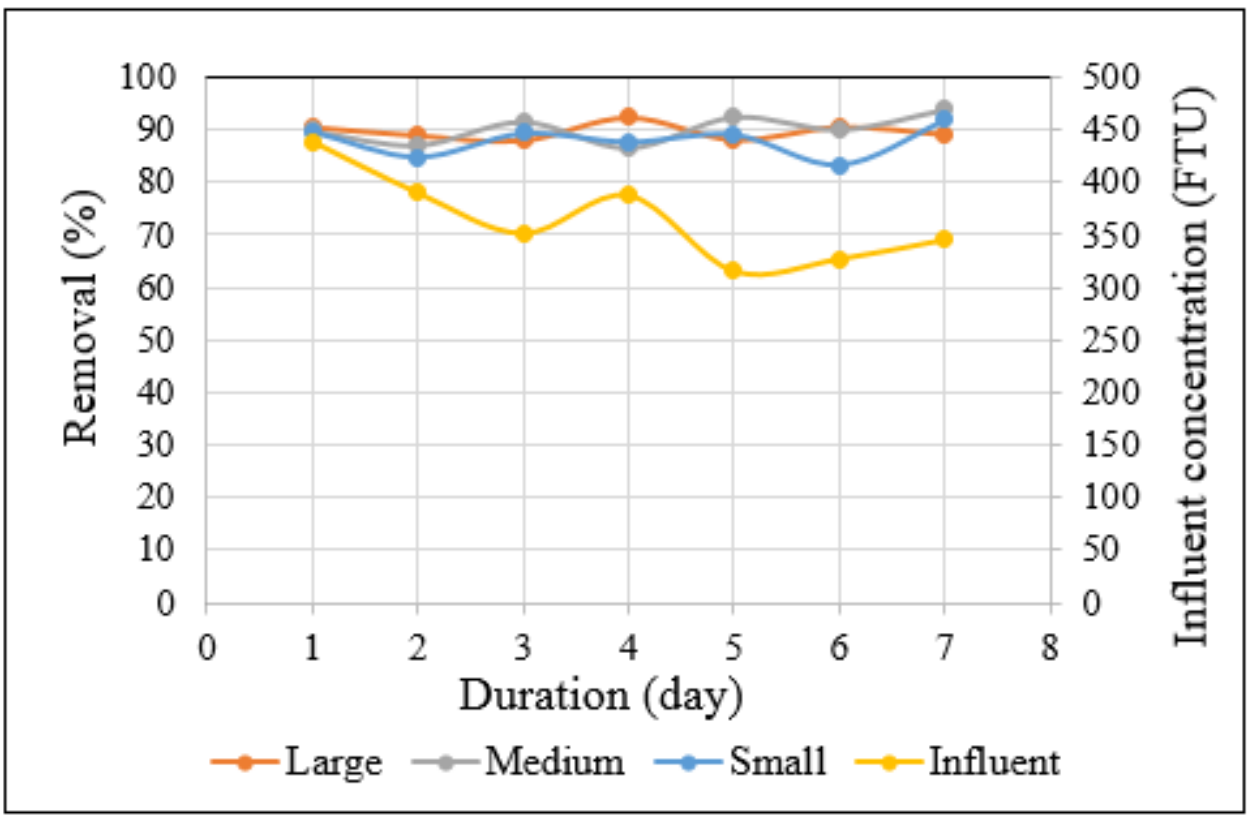

Figure 4: Turbidity removal efficiency for disposed PVC pipe parts BTFs in adaptation phase

\section{DESIGN OF EXPERIMENTS USING RSM}

In this work, CCD and RSM were applied to evaluate the relationship between the most significant operating variables, i.e., filter media size $(2.5,5$, and $7.5 \mathrm{~cm})$ and filter media depth $(30,60$, and $90 \mathrm{~cm})$, and their responses (COD, EC, turbidity, and color). The range and levels of the independent variables are shown in Table 2 . The operating variables were optimized to predict the best value of responses.

Table 2: Experimental range and levels of the independent variables

\begin{tabular}{|c|c|c|c|c|c|}
\hline Code & Factors (variables) & Unit & \multicolumn{3}{|c|}{ Range and levels } \\
\hline & & & -1 & 0 & +1 \\
\hline A & Filter depth & $\mathrm{cm}$ & 30 & 60 & 90 \\
\hline B & Filter size & $\mathrm{cm}$ & 2.5 & 5 & 7.5 \\
\hline
\end{tabular}




\section{RESULTS AND DISCUSSIONS}

After seven days of operation (i.e., one-week adaptation phase of BTFs) for each filter media type, the RSM experiments were directly conducted. The results are shown in Tables 3, 4, and 5.

Table 3: Experimental variables and results for rock BTFs

\begin{tabular}{|c|c|c|c|c|c|c|}
\hline \multirow{3}{*}{ Run } & \multicolumn{2}{|c|}{ Variables } & \multicolumn{4}{c|}{ Removal of Responses } \\
\cline { 2 - 7 } & A: Filter depth & B: Filter size & COD & EC & Turbidity & Color \\
\cline { 2 - 7 } & $\mathrm{cm}$ & $\mathrm{cm}$ & $\%$ & $\%$ & $\%$ & $\%$ \\
\hline 1 & 30 & 2.5 & 88.00 & 4.10 & 87.60 & 87.00 \\
\hline 2 & 90 & 5 & 89.90 & 5.33 & 89.50 & 88.50 \\
\hline 3 & 30 & 7.5 & 88.00 & 2.54 & 87.00 & 86.6 \\
\hline 4 & 60 & 7.5 & 89.00 & 3.00 & 88.21 & 87.00 \\
\hline 5 & 60 & 5 & 88.98 & 4.34 & 88.30 & 87.10 \\
\hline 6 & 90 & 7.5 & 89.90 & 4.76 & 89.80 & 88.00 \\
\hline 7 & 60 & 5 & 89.40 & 3.79 & 87.12 & 87.83 \\
\hline 8 & 60 & 5 & 88.50 & 4.54 & 88.50 & 86.90 \\
\hline 9 & 30 & 5 & 88.23 & 3.00 & 86.93 & 86.61 \\
\hline 10 & 90 & 2.5 & 90.50 & 5.50 & 89.60 & 88.50 \\
\hline 11 & 60 & 5 & 89.20 & 3.78 & 87.64 & 87.30 \\
\hline 12 & 60 & 2.5 & 88.50 & 5.00 & 88.00 & 87.60 \\
\hline 13 & 60 & 5 & 89.00 & 3.00 & 87.00 & 87.40 \\
\hline
\end{tabular}

Table 4: Experimental variables and results for disposed plastic cap BTFs

\begin{tabular}{|c|c|c|c|c|c|c|}
\hline \multirow{3}{*}{ Run } & \multicolumn{3}{|c|}{ Variables } & \multicolumn{4}{c|}{ Removal of Responses } \\
\cline { 2 - 7 } & A: Filter depth & B: Filter size & COD & EC & Turbidity & Color \\
\cline { 2 - 7 } & $\mathrm{cm}$ & $\mathrm{cm}$ & $\%$ & $\%$ & $\%$ & $\%$ \\
\hline 1 & 30 & 2.5 & 89.00 & 6.20 & 90.59 & 85.70 \\
\hline 2 & 90 & 5 & 90.72 & 5.55 & 89.00 & 85.00 \\
\hline 3 & 30 & 7.5 & 88.78 & 4.56 & 90.01 & 83.50 \\
\hline 4 & 60 & 7.5 & 89.00 & 4.67 & 88.20 & 84.00 \\
\hline 5 & 60 & 5 & 90.29 & 4.99 & 88.40 & 84.21 \\
\hline 6 & 90 & 7.5 & 90.30 & 5.00 & 90.04 & 84.18 \\
\hline 7 & 60 & 5 & 90.23 & 5.43 & 88.51 & 83.40 \\
\hline 8 & 60 & 5 & 90.21 & 5.23 & 88.90 & 84.60 \\
\hline 9 & 30 & 5 & 89.86 & 4.67 & 88.00 & 84.11 \\
\hline 10 & 90 & 2.5 & 90.46 & 6.40 & 90.95 & 86.96 \\
\hline 11 & 60 & 5 & 90.10 & 5.30 & 88.43 & 83.69 \\
\hline 12 & 60 & 2.5 & 90.30 & 6.50 & 90.60 & 86.44 \\
\hline 13 & 60 & 5 & 90.06 & 5.17 & 88.32 & 84.90 \\
\hline
\end{tabular}

Table 5: Experimental variables and results for disposed PVC pipe part BTFs

\begin{tabular}{|c|c|c|c|c|c|c|}
\hline \multirow{3}{*}{ Run } & \multicolumn{2}{|c|}{ Variables } & \multicolumn{4}{c|}{ Removal of Responses } \\
\cline { 2 - 7 } & A: Filter depth & B: Filter size & COD & EC & Turbidity & Color \\
\cline { 2 - 7 } & $\mathrm{cm}$ & $\mathrm{cm}$ & $\%$ & $\%$ & $\%$ & $\%$ \\
\hline 1 & 30 & 2.5 & 89.00 & 4.47 & 88.24 & 81.85 \\
\hline 2 & 90 & 5 & 88.89 & 4.50 & 91.38 & 86.50 \\
\hline 3 & 30 & 7.5 & 85.20 & 2.30 & 88.91 & 83.30 \\
\hline 4 & 60 & 7.5 & 85.60 & 2.45 & 89.30 & 84.00 \\
\hline 5 & 60 & 5 & 88.57 & 3.78 & 90.23 & 84.53 \\
\hline 6 & 90 & 7.5 & 86.16 & 2.67 & 89.90 & 84.44 \\
\hline 7 & 60 & 5 & 89.00 & 3.60 & 90.54 & 86.10 \\
\hline 8 & 60 & 5 & 88.20 & 3.00 & 90.37 & 83.77 \\
\hline 9 & 30 & 5 & 87.67 & 3.00 & 89.02 & 83.50 \\
\hline 10 & 90 & 2.5 & 89.86 & 5.47 & 90.50 & 84.09 \\
\hline 11 & 60 & 5 & 88.67 & 4.07 & 89.90 & 83.67 \\
\hline 12 & 60 & 2.5 & 89.5 & 5.00 & 89.50 & 82.00 \\
\hline 13 & 60 & 5 & 88.89 & 4.17 & 90.48 & 83.89 \\
\hline
\end{tabular}


Figure 5a indicates that the value of COD removal for rock BTFs increased from $88 \%$ to $90.5 \%$ with the increase in filter depth from 30 to $90 \mathrm{~cm}$. By contrast, an increase in filter size had no effect on COD removal (less significant). Notably, an increase in filter media depth leads to more organic load and will increase microbial growth activity within the BTFs. However, a low specific surface area (SSA) of large filter size may decrease the COD removal efficiency because less biofilm was able to grow on the surface of the media [13].

Figure $5 \mathrm{~b}$ clearly indicates that the removal of COD response for disposed of plastic cap BTF significantly increased to $88.73 \%$ and $90.72 \%$ with the increase in filter depth from $30 \mathrm{~cm}$ to $90 \mathrm{~cm}$, respectively. From a filter size of 2.5 to $5 \mathrm{~cm}$, COD removal increased and reached its maximum value of $90.72 \%$ at a filter size of $5 \mathrm{~cm}$. When the filter size increased from $5 \mathrm{~cm}$ to $7.5 \mathrm{~cm}$, the COD response decreased to $88.5 \%$.

By contrast, an inverse relationship was found between the filter media size and COD removal in Figure 5c for disposed PVC pipe BTFs because of the large pores in this media, this caused the synthetic dairy wastewater to directly reach the bottom of BTFs without allowing biofilm growth activity to degrade the organic matter in the wastewater on the surface of filter media particles. Thus, a high void ratio was obtained in the disposed PVC pipe part filter than in the other two types of filter media. However, a moderate increase in filter media size from $2.5 \mathrm{~cm}$ to $5 \mathrm{~cm}$ resulted in increased COD removal efficiency. In summary, the average removal efficiency of RSM results for rock, disposed of plastic caps, and disposed PVC pipe parts was $89 \%, 89.96 \%$, and $88.09 \%$, respectively. The maximum COD removal efficiency was in the disposed plastic cap filter media because of the high SSA and void ratio also the roughness of the filter media, which created a suitable condition that enabled microorganisms to adhere to the surface areas. The results of this study are better than those of Lemji and Eckstadt [14], who obtained an average reduction of $88 \%$ and $84.42 \pm 6.5 \%$ for COD value for plastic bio-cache BTF system and pebble gravel BTF, respectively.

a) Rock BTF

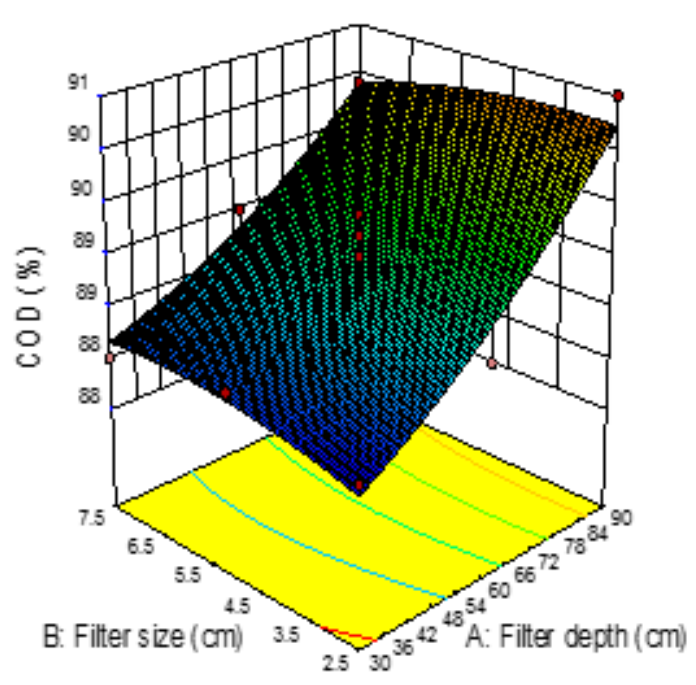

b) Disposed plastic cap BTF

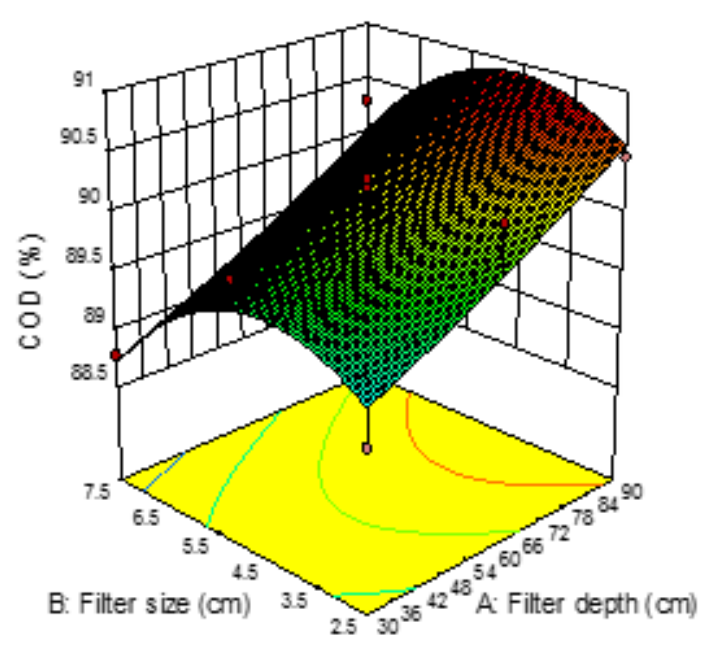

c) Disposed PVC pipe parts BTF

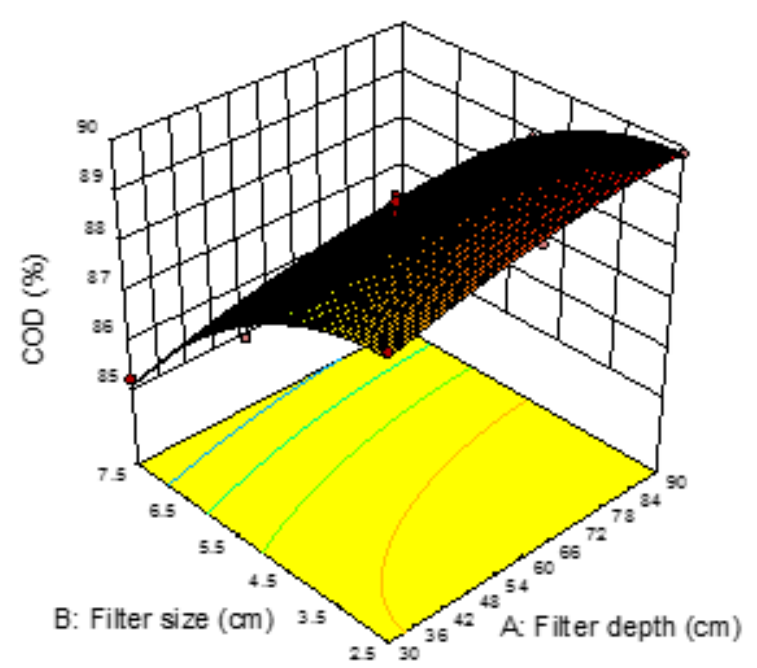

Figure 5: Design-expert plot; response surface 3D plot for COD removal 
One of the measured parameters for evaluating the removal efficiency of the BTF columns was EC. Figure 6a indicates that a minimum EC removal efficiency of $2.54 \%$ was achieved at $30 \mathrm{~cm}$ filter depth and $7.5 \mathrm{~cm}$ filter in rock BTF. The removal of EC response was increased with the increase in filter depth for all BTFs. Furthermore, an increase in filter size led to a slight decrease in EC removal efficiency. The maximum removal efficiency of EC $6.5 \%$ was obtained at $60 \mathrm{~cm}$ filter depth and $2.5 \mathrm{~cm}$ filter size of the disposed of plastic cap BTF. The average EC removal efficiencies of the RSM results of $4.05 \%$, 5.35\%, and $3.72 \%$ were obtained for rock, disposed plastic caps, and disposed PVC pipe part BTFs, respectively. The disposed plastic caps achieved maximum EC removal, and the overall EC removal efficiencies were low.

BTF is a kind of attached growth biological (secondary) treatment process. Normally, in the biological treatment processes most parts of organic matters are removed [15]. As mentioned in the previous section that most parts of COD removed in the BTFs. While EC related to soluble salts and the BTFs commonly are inefficient in the removal of EC.

a) Rock

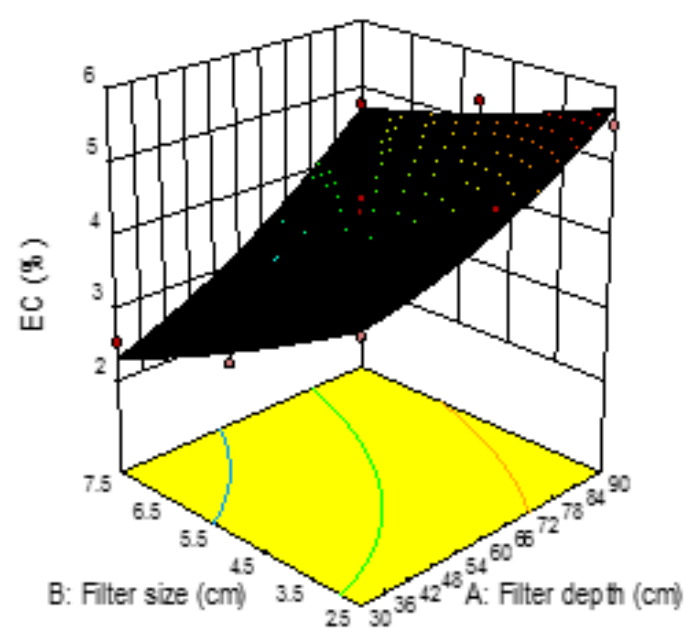

b) Disposed plastic caps

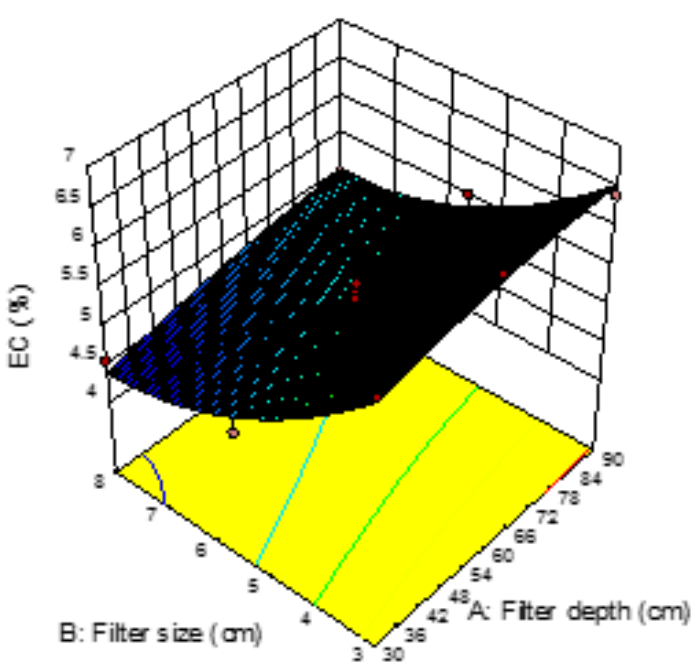

\section{c) Disposed PVC pipe parts}

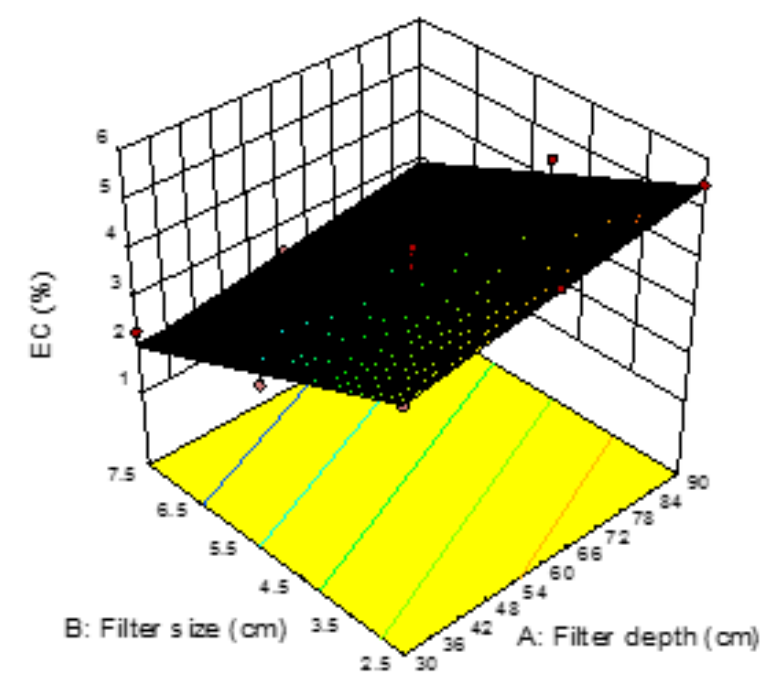

Figure 6: Design-expert plot; response surface 3D plot for EC removal

iii. Turbidity removal

For all BTFs in Figure 7, the removal efficiency of turbidity was increased with the increase in filter depth and reached its maximum value of $91.38 \%$ at a $90 \mathrm{~cm}$ filter depth for disposed of PVC BTF. In the current work, Figure 7 illustrated that the filter media size had no noticeable influence on turbidity removal. For a medium filter size, the removal was decreased to its minimum value of $87 \%$ and $88 \%$ for rock and disposed plastic cap BTFs, respectively. Most of the turbidity was removed by sedimentation in the effluent sample because of the large size of the disposed PVC filter, because the feed wastewater rapidly flowed to the bottom of the column and resulted in a high void ratio, which did not allow the wastewater to remain in the columns long enough to develop sufficient biofilm activity. The average turbidity removal values for rock, disposed plastic caps, and disposed PVC pipe parts were $88.13 \%$, $89.22 \%$, and $89.86 \%$, respectively. The maximum turbidity removal was recorded from disposed PVC pipe part BTFs. The low turbidity removal was also a good indicator for the assessment of biofilm 
increase on the rock and disposed plastic cap filter media during the test period. This finding is following the results obtained by Shahriari and Shokouhi [9].

a) Rock

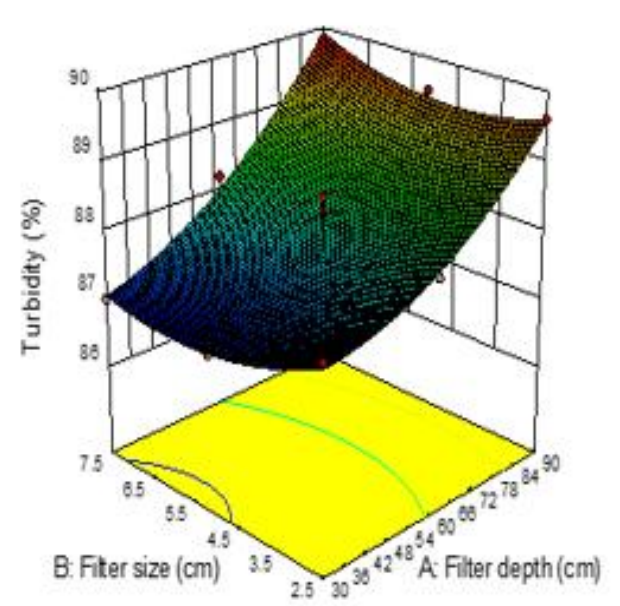

b) Disposed plastic caps

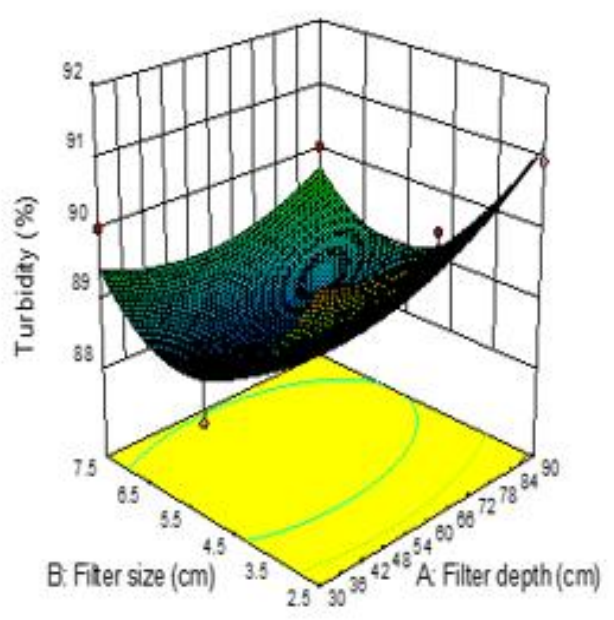

c) Disposed PVC pipe parts

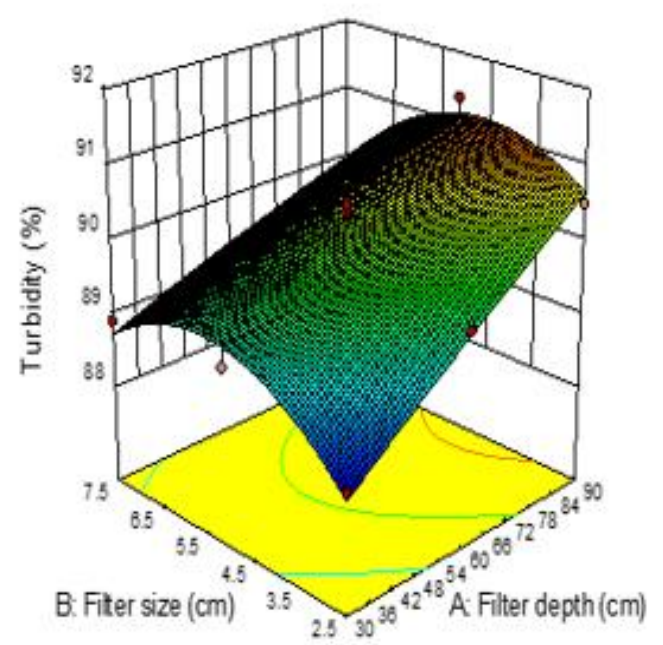

Figure 7: Design-expert plot; response surface 3D plot for Turbidity removal

iv. Color removal

As shown in Figure 8a, apparent color removal was improved because of an increase in filter media size from $2.5 \mathrm{~cm}$ to $7.5 \mathrm{~cm}$. Figure $8 \mathrm{~b}$ shows that the increase in filter depth at a constant filter size (from $2.5 \mathrm{~cm}$ to $5 \mathrm{~cm}$ ) did not have a significant effect, whereas a filter size greater than $5 \mathrm{~cm}$ showed a reducing effect on apparent color removal. The apparent color response was increased evidently with the increase in variables, Figure 8c. The average apparent color removal values for rock, disposed of plastic caps, and disposed PVC pipe parts were $87.41 \%, 84.66 \%$, and 83.97\%, respectively. The maximum average apparent color removal efficiency was obtained from rock BTFs. 


\section{a) Rock}

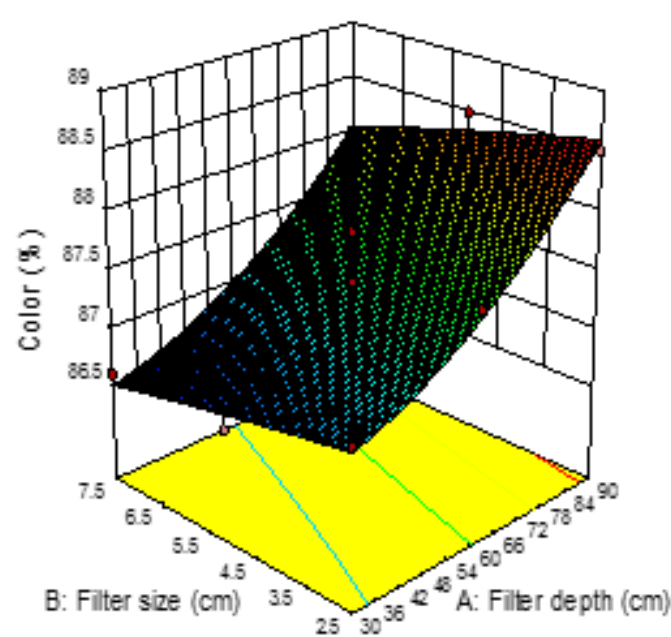

b) Disposed plastic caps

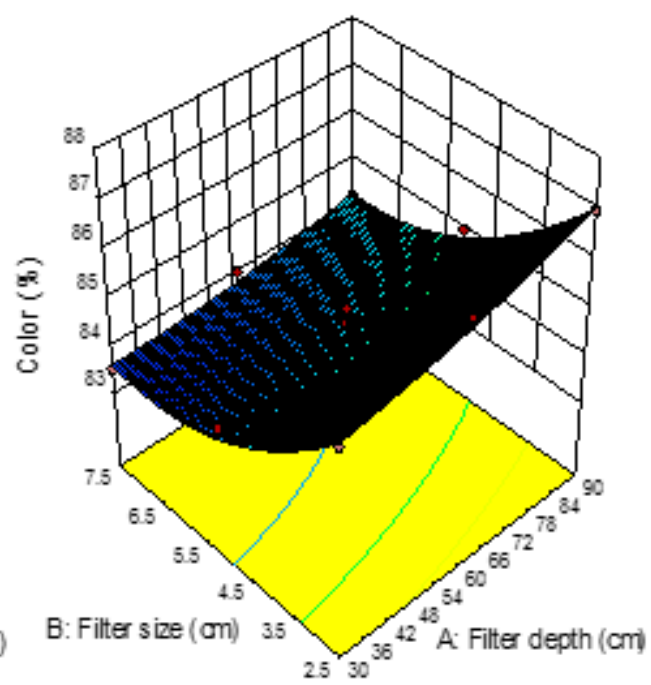

\section{c) Disposed PVC pipe parts}

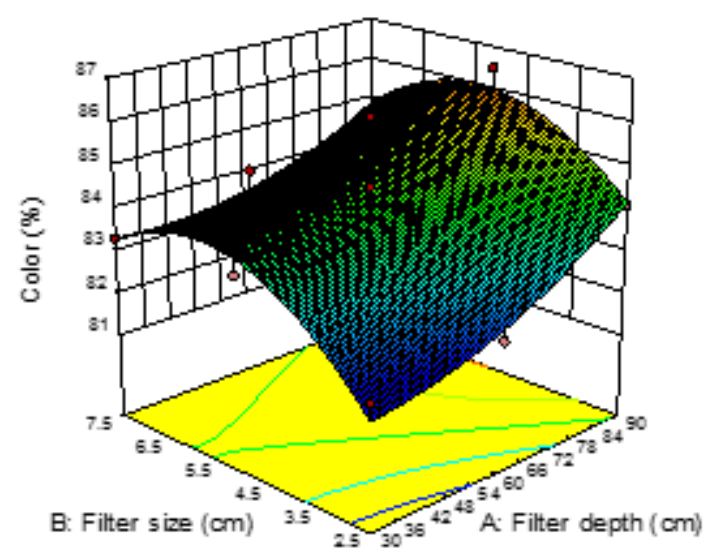

Figure 8: Design-expert plot; response surface 3D plot for Color removal

\subsection{Statistical Analysis}

For various investigated responses in this study, considerable model terms were preferred to achieve the best fit in a particular model. To quantify the curvature effects, the data from the experimental results were fitted to higher-degree polynomial equations, i.e., two-factor interaction and quadratic. Some raw data might not be fitted, and transformations that apply a mathematical function to all the response data might be needed to meet the assumptions that make the analysis of variance (ANOVA) valid [16]. The ANOVA results for all responses are summarized in Table 6. The selected model terms aim to eliminate insignificant variables and their interactions. CCD permitted the development of a mathematical equation in which predicted results (Y) are evaluated as a function of filter depth (A) and filter size (B). The result was computed as the sum of a constant, two first-order effects (terms in $A$ and $B$ ), one interaction effect (AB), and two second-order effects $\left(A^{2}\right.$ and $\left.B^{2}\right)$, as shown in Table 6.

The ANOVA results indicated the reduced quadratic models in terms of actual factors and also showed other statistical parameters. All models were highly significant because the probability values were less than 0.05 . The lack-of-fit (LOF) F-value explains the variation of the data around the modified model. On the basis of statistical analysis, the models were highly significant with very low probability values $<0.0001$ as shown in Table 6. LOF is significant if the model does not fit the data well [17]. Commonly, a significant probability value for LOF $(>0.05)$ indicates that the F-statistic is insignificant. The coefficient of determination $\left(\mathrm{R}^{2}\right)$ values close to 1 are desirable, and a high $\mathrm{R}^{2}$ coefficient ensures acceptable modification of the quadratic model to the experimental data. Adequate precision values were helpful for all models because they were greater than 4. If the coefficient of variance (CV) of the model is greater than $10 \%$, then the model is considered reproducible [17].

The suitability of the model could be judged by diagnostic plots, i.e., predicted vs. actual values. Figures 9 to 11 showed the predicted vs. actual value plots of the response parameters for all rock, disposed plastic caps, and disposed PVC pipe part BTF types, respectively. These plots signify sufficient agreement between real data and the ones that were achieved from the models. The values of $\mathrm{R}^{2}$ and adjusted $\mathrm{R}^{2}$ were evaluated, and good understanding was found between the predicted and actual data. 


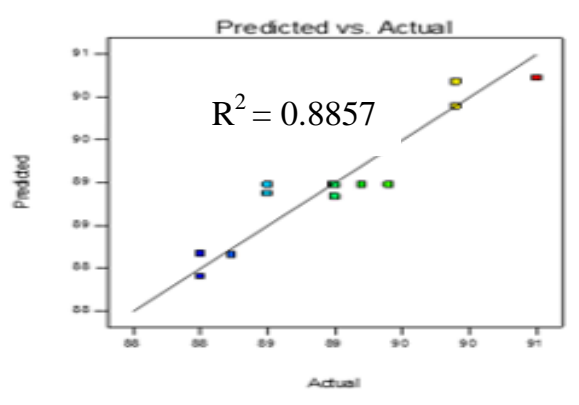

A

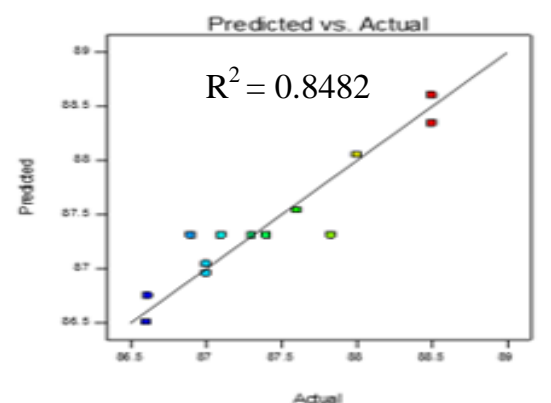

c

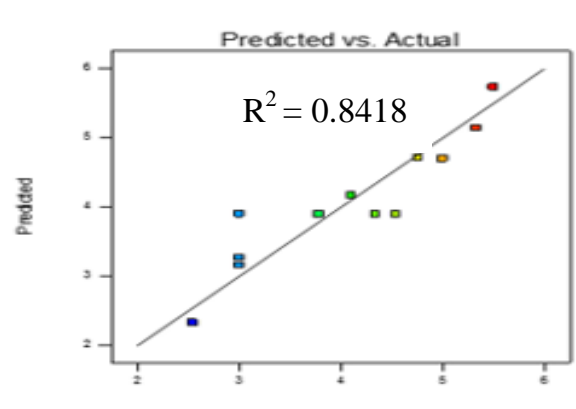

Actual

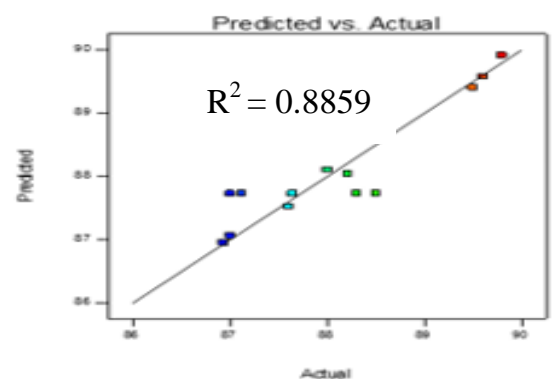

$\mathrm{D}$

Figure 9: Design-expert plot; predicted vs. actual plot for rock BTFs: (A) COD removal, (B) Ec removal, (C) turbidity removal, and (D) color removal

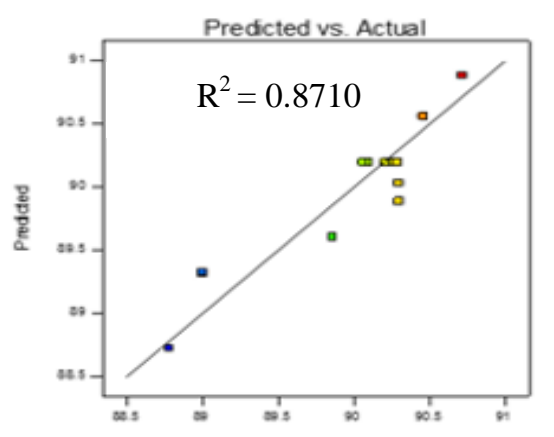

A

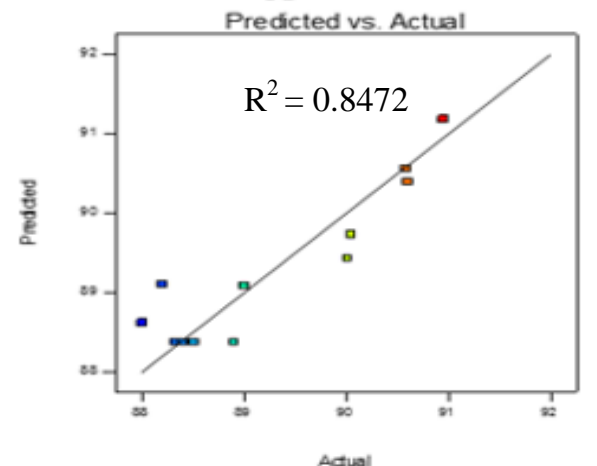

C

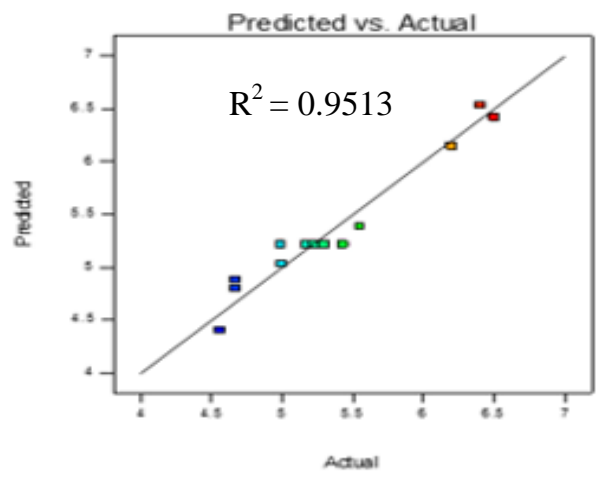

B

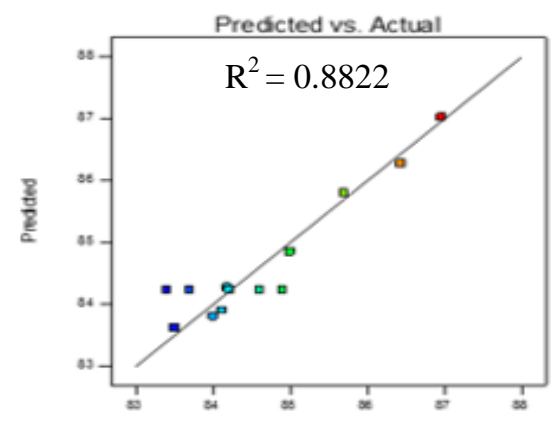

D

Figure 10: Design-expert plot; predicted vs. actual plot for disposed plastic cap BTFs: (A) COD removal, (B) Ec removal, (C) turbidity removal, and (D) color removal. 


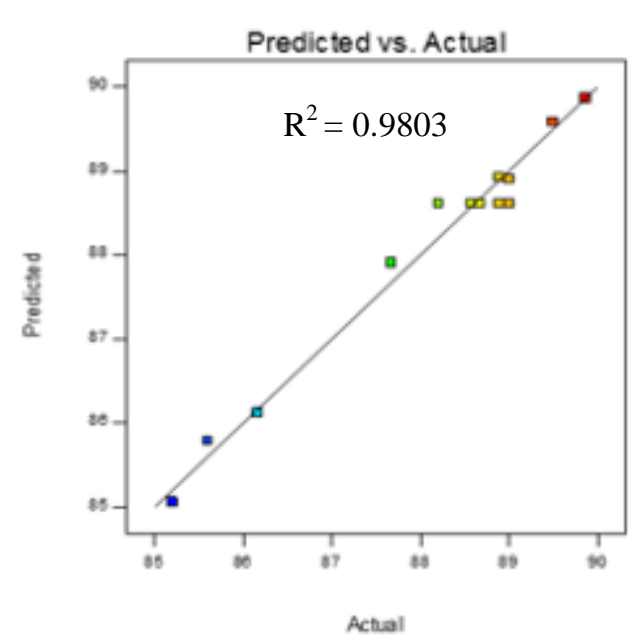

A

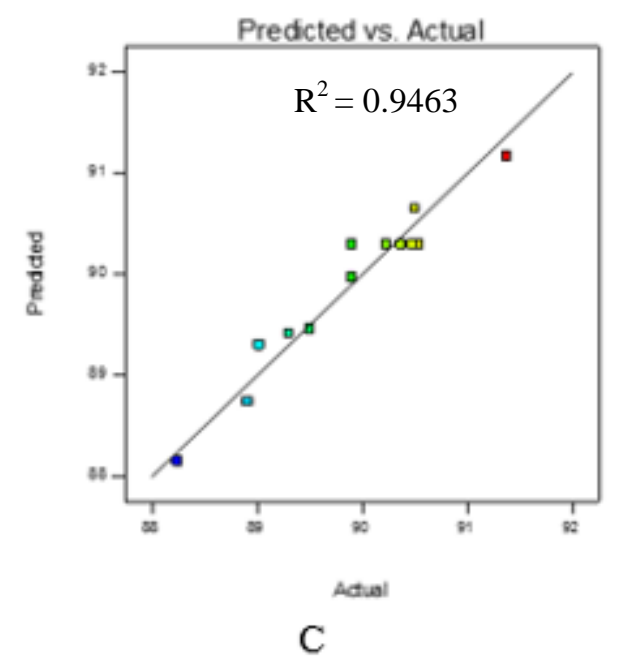

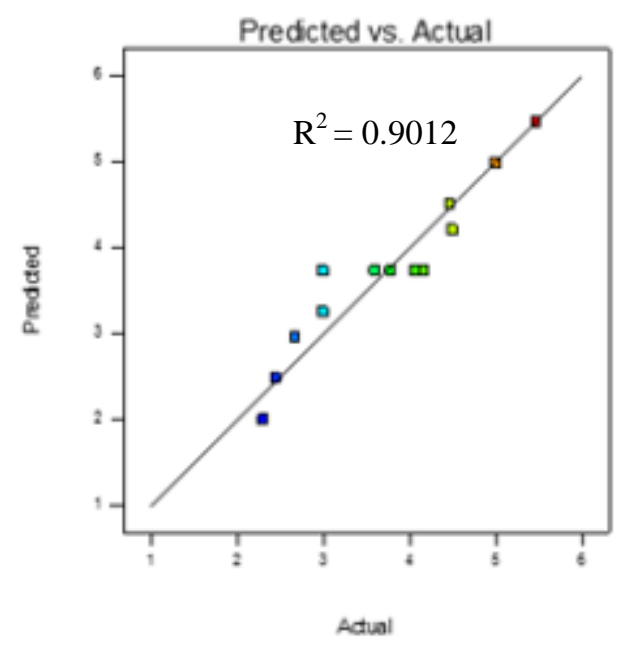

B

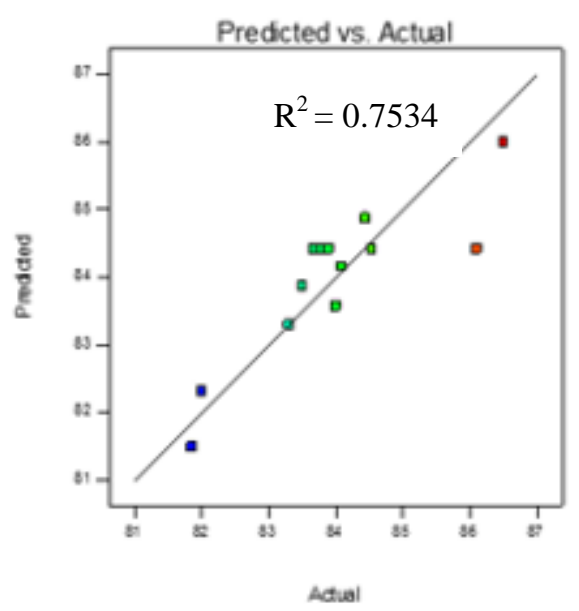

$\mathrm{D}$

Figure 11: Design-expert plot; predicted vs. actual plot for disposed PVC BTFs: (A) COD removal, (B) Ec removal, (C) turbidity removal, and (D) color removal.

\subsection{Experimental Condition Optimization}

RSM was used to identify independent variables (filter depth and filter size) that produce optimum values of the responses (COD, EC, turbidity, and colour removals). In optimization, both independent variables were individually increased or decreased to find the optimum practical reactions. Subsequently, these optimum variables were selected as the conditions for obtaining the best results [17]. Table 7 illustrated the chosen response value for each parameter. The selected constraints were relatively close to the acquired maximum removal and practicability standards of treatment plants. The optimization of experimental conditions was identified by considering whether the rates of COD, EC, turbidity, and colour values were higher than randomly selected limitation values. Three optimum conditions were predicted by Design-Expert Software for three BTF types. On the basis of the CCD model results, all three optimal operating conditions occurred for the rock, disposed of plastic cap, and disposed PVC pipe part BTFs at a filter media depth of $60 \mathrm{~cm}$ and filter media size of $5 \mathrm{~cm}$. 
Citation Shuokr Qarani Aziz and Sazan Mohammed Ali., 2019. Treatment of Synthetic Dairy Wastewater Using Disposed Plastic Materials as Trickling Filter Media: Optimization and Statistical Analysis by RSM. Advances in Environmental Biology., 13(10): 1-16 DOI:10.22587/aeb.2019.13.10.1

Table 6: ANOVA results for response parameters

\begin{tabular}{|c|c|c|c|c|c|c|c|c|c|c|}
\hline $\begin{array}{l}\text { BTF } \\
\text { type }\end{array}$ & $\begin{array}{c}\text { Respo } \\
\text { nses }\end{array}$ & Final equation in terms of actual factors & $\begin{array}{l}\text { Pro } \\
\text { b. }\end{array}$ & $\mathrm{R}^{2}$ & $\begin{array}{c}\text { Adj. } \\
\mathrm{R}^{2}\end{array}$ & $\begin{array}{l}\text { Ade } \\
\text { q. P }\end{array}$ & $\begin{array}{l}\mathrm{S} \\
\mathrm{D} \\
\end{array}$ & $\begin{array}{c}\mathrm{CV} \\
\% \\
\end{array}$ & $\begin{array}{c}\text { Pre } \\
\text { ss }\end{array}$ & $\begin{array}{c}\mathrm{LO} \\
\mathrm{F}\end{array}$ \\
\hline \multirow{4}{*}{ 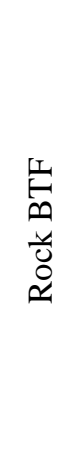 } & COD & $\begin{array}{c}86.679+0.0178142 \mathrm{~A}+0.306437 \mathrm{~B}+-0.002 \mathrm{AB}+ \\
0.0002159 \mathrm{~A}^{2}+-0.0193103 \mathrm{~B}^{2}\end{array}$ & $\begin{array}{l}0.0 \\
034\end{array}$ & $\begin{array}{l}0.8 \\
857\end{array}$ & $\begin{array}{c}0.80 \\
41\end{array}$ & $\begin{array}{l}10 . \\
001\end{array}$ & $\begin{array}{l}0 . \\
34\end{array}$ & $\begin{array}{c}0.3 \\
8\end{array}$ & $\begin{array}{c}4.2 \\
1\end{array}$ & $\begin{array}{c}0.3 \\
7\end{array}$ \\
\hline & $\mathrm{EC}$ & $\begin{array}{c}5.51379+-0.0140594 \mathrm{~A}+-0.588046 \mathrm{~B}+0.00273333 \mathrm{AB}+ \\
0.000278736 \mathrm{~A}^{2}+0.0137379 \mathrm{~B}^{2}\end{array}$ & $\begin{array}{l}0.0 \\
100\end{array}$ & $\begin{array}{l}0.8 \\
418\end{array}$ & $\begin{array}{c}0.72 \\
88\end{array}$ & $\begin{array}{l}9.9 \\
96\end{array}$ & $\begin{array}{l}0 . \\
5\end{array}$ & $\begin{array}{l}12 . \\
42\end{array}$ & $\begin{array}{c}5.4 \\
8\end{array}$ & $\begin{array}{c}0.3 \\
3\end{array}$ \\
\hline & $\begin{array}{l}\text { Turbi } \\
\text { dity }\end{array}$ & $\begin{array}{c}89.3005+-0.0325038 \mathrm{~A}+-0.718046 \mathrm{~B}+0.00266667 \mathrm{AB}+ \\
0.000500958 \mathrm{~A}^{2}+0.0545379 \mathrm{~B}^{2}\end{array}$ & $\begin{array}{l}0.0 \\
088\end{array}$ & $\begin{array}{l}0.8 \\
482\end{array}$ & $\begin{array}{c}0.73 \\
97\end{array}$ & $\begin{array}{l}8.3 \\
73\end{array}$ & $\begin{array}{l}0 . \\
52\end{array}$ & $\begin{array}{c}0.5 \\
9\end{array}$ & $\begin{array}{c}3.3 \\
9\end{array}$ & $\begin{array}{r}0.0 \\
74\end{array}$ \\
\hline & Color & $\begin{array}{c}86.992+-0.00337739 A+-0.0518621 B+- \\
0.000333333 A B+0.000263793 A^{2}+0.00281379 B^{2}\end{array}$ & $\begin{array}{l}0.0 \\
034\end{array}$ & $\begin{array}{l}0.8 \\
859\end{array}$ & $\begin{array}{c}0.80 \\
45\end{array}$ & $\begin{array}{l}10 . \\
881\end{array}$ & $\begin{array}{l}0 . \\
28\end{array}$ & $\begin{array}{c}0.3 \\
2\end{array}$ & $\begin{array}{c}1.4 \\
5\end{array}$ & $\begin{array}{l}0.0 \\
72\end{array}$ \\
\hline \multirow{4}{*}{ 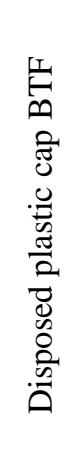 } & COD & $\begin{array}{c}87.381+0.0135747 \mathrm{~A}+0.818897 \mathrm{~B}+0.0002 \mathrm{AB}+ \\
5.63218 \mathrm{E}-005 \mathrm{~A}^{2}+-0.0942897 \mathrm{~B}^{2}\end{array}$ & $\begin{array}{l}0.0 \\
051\end{array}$ & $\begin{array}{l}0.8 \\
71\end{array}$ & $\begin{array}{c}0.77 \\
88\end{array}$ & $\begin{array}{l}10 . \\
970\end{array}$ & $\begin{array}{l}0 . \\
29\end{array}$ & $\begin{array}{c}0.3 \\
2\end{array}$ & $\begin{array}{c}5.6 \\
6\end{array}$ & $\begin{array}{c}0.5 \\
5\end{array}$ \\
\hline & $\mathrm{EC}$ & $\begin{array}{c}7.82563+0.0152031 \mathrm{~A}+-1.00356 \mathrm{~B}+0.0008 \mathrm{AB}+- \\
8.96552 \mathrm{E}-005 \mathrm{~A}^{2}+0.0630897 \mathrm{~B}^{2}\end{array}$ & $\begin{array}{l}0.0 \\
002\end{array}$ & $\begin{array}{l}0.9 \\
513\end{array}$ & $\begin{array}{c}0.91 \\
65\end{array}$ & $\begin{array}{l}16 . \\
732\end{array}$ & $\begin{array}{l}0 . \\
19\end{array}$ & $\begin{array}{c}3.5 \\
0\end{array}$ & $\begin{array}{c}1.5 \\
7\end{array}$ & $\begin{array}{c}0.1 \\
4\end{array}$ \\
\hline & $\begin{array}{l}\text { Turbi } \\
\text { dity }\end{array}$ & $\begin{array}{c}96.2789+-0.0501571 \mathrm{~A}+-2.39389 \mathrm{~B}+-0.0011 \mathrm{AB}+ \\
0.000528161 \mathrm{~A}^{2}+0.220055 \mathrm{~B}^{2}\end{array}$ & $\begin{array}{l}0.0 \\
090\end{array}$ & $\begin{array}{l}0.8 \\
472\end{array}$ & $\begin{array}{c}0.73 \\
8\end{array}$ & $\begin{array}{l}7.6 \\
73\end{array}$ & $\begin{array}{l}0 . \\
54\end{array}$ & $\begin{array}{c}0.6 \\
1\end{array}$ & $\begin{array}{l}16 . \\
63\end{array}$ & $\begin{array}{c}1.8 \\
4\end{array}$ \\
\hline & Color & $\begin{array}{c}88.9562+0.00683716 \mathrm{~A}+-1.66529 \mathrm{~B}+-0.00193333 \mathrm{AB}+ \\
0.000154598 \mathrm{~A}^{2}+0.128662 \mathrm{~B}^{2}\end{array}$ & $\begin{array}{l}0.0 \\
038\end{array}$ & $\begin{array}{l}0.8 \\
822\end{array}$ & $\begin{array}{c}0.79 \\
81\end{array}$ & $\begin{array}{l}10 . \\
090\end{array}$ & $\begin{array}{l}0 . \\
50\end{array}$ & $\begin{array}{c}0.5 \\
9\end{array}$ & 3.6 & 0.2 \\
\hline \multirow{4}{*}{ 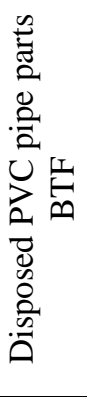 } & COD & $\begin{array}{c}87.0008+0.0415211 \mathrm{~A}+0.703586 \mathrm{~B}+0.000333333 \mathrm{AB}+ \\
-0.000219157 \mathrm{~A}^{2}+-0.148359 \mathrm{~B}^{2}\end{array}$ & $\begin{array}{l}0.0 \\
001\end{array}$ & $\begin{array}{l}0.9 \\
803\end{array}$ & $\begin{array}{c}0.96 \\
63\end{array}$ & $\begin{array}{l}25 . \\
673\end{array}$ & $\begin{array}{l}0 . \\
28\end{array}$ & $\begin{array}{c}0.3 \\
1\end{array}$ & $\begin{array}{c}1.6 \\
9\end{array}$ & $\begin{array}{c}0.1 \\
4\end{array}$ \\
\hline & $\mathrm{EC}$ & $5.27923+0.0159444 \mathrm{~A}+-0.501333 \mathrm{~B}$ & $\begin{array}{l}0.0 \\
001\end{array}$ & $\begin{array}{l}0.9 \\
012\end{array}$ & $\begin{array}{c}0.88 \\
14\end{array}$ & $\begin{array}{l}20 . \\
949\end{array}$ & $\begin{array}{l}0 . \\
34\end{array}$ & $\begin{array}{c}9.2 \\
3\end{array}$ & $\begin{array}{c}1.7 \\
7\end{array}$ & $\begin{array}{c}0.3 \\
2\end{array}$ \\
\hline & $\begin{array}{c}\text { Turbi } \\
\text { dity }\end{array}$ & $\begin{array}{c}83.5096+0.0604462 \mathrm{~A}+1.62269 \mathrm{~B}+-0.00423333 \mathrm{AB}+- \\
6.76074 \mathrm{E}-005 \mathrm{~A}^{2}+-0.137735 \mathrm{~B}^{2} \\
\end{array}$ & $\begin{array}{l}0.0 \\
003\end{array}$ & $\begin{array}{l}0.9 \\
463\end{array}$ & $\begin{array}{c}0.90 \\
8\end{array}$ & $\begin{array}{l}17 . \\
274\end{array}$ & $\begin{array}{l}0 . \\
26\end{array}$ & $\begin{array}{c}0.2 \\
9\end{array}$ & $\begin{array}{c}2.4 \\
4\end{array}$ & 0.2 \\
\hline & Color & $\begin{array}{c}76.0518+-0.0149614 \mathrm{~A}+2.84846 \mathrm{~B}+-0.00366667 \mathrm{AB}+ \\
0.000572826 \mathrm{~A}^{2}+-0.237513 \mathrm{~B}^{2}\end{array}$ & $\begin{array}{l}0.0 \\
42\end{array}$ & $\begin{array}{l}0.7 \\
534\end{array}$ & $\begin{array}{c}0.57 \\
73\end{array}$ & $\begin{array}{l}7.7 \\
85\end{array}$ & $\begin{array}{l}0 . \\
85\end{array}$ & $\begin{array}{c}1.0 \\
2\end{array}$ & $\begin{array}{l}16 . \\
08\end{array}$ & 1.0 \\
\hline
\end{tabular}

A: filter depth $(\mathrm{cm})$; B: filter size $(\mathrm{cm})$; Prob.: probability of error; $\mathrm{R}^{2}$ : coefficient of determination; Adj. $\mathrm{R}^{2}$ : adjusted $\mathrm{R}^{2}$; Adeq. P.: adequate precision; SD: standard deviation; CV: coefficient of variance; Press: predicted residual error sum of squares; and LOF: lack of Fit

As shown in Table 7, the highest predicted removal efficiencies of COD and EC of disposed plastic caps were 90.19\% and $5.21 \%$ higher, respectively than those of the other BTFs. This finding was due to the fact that the disposed plastic cap medium size had a large SSA and good void ratio, which allowed the bacteria to adhere to the filter surface to grow the biofilm layer and enabled wastewater to flow easily within the particles. The obtained result was in agreement with data published by Zinatizadeh et al. [18]. The highest turbidity removal was $90.29 \%$ for PVC pipe pieces and $87.3 \%$ for color removal by river rock BTF.

Table 7: The value of responses at optimum conditions given by RSM

\begin{tabular}{|c|c|c|c|c|c|c|}
\hline \multirow{2}{*}{ BTF type } & \multicolumn{3}{|c|}{ Removal of Responses \% } & \multicolumn{2}{c|}{ Filter Media } \\
\cline { 2 - 7 } & COD & EC & Turbidity & Color & $\begin{array}{c}\text { Size } \\
(\mathrm{cm})\end{array}$ & $\begin{array}{c}\text { Depth } \\
(\mathrm{cm})\end{array}$ \\
\hline Rock & 88.97 & 3.89 & 87.72 & 87.3 & 5 & 60 \\
\hline Disposed plastic caps & 90.19 & 5.21 & 88.37 & 84.23 & 5 & 60 \\
\hline Disposed PVC pipe parts & 88.61 & 3.72 & 90.29 & 84.42 & 5 & 60 \\
\hline
\end{tabular}

On the basis of the removal efficiencies of RSM values, the effectiveness of COD, EC, and colour removal efficiencies in optimized conditions was as follows: disposed plastic cap > rock > disposed PVC pipe parts. Thus, a greater amount of biomass was adhered to the disposed plastic caps than to the rock and the disposed PVC pipe parts. The same result was obtained by Zhang et al. [13]. The rock filter media had a smaller SSA and void ratio than the disposed PVC filter media. However, the rough surface of the rock filter media was enabled more bacteria to adhere to and develop on the surface than on the disposed PVC pipe parts, which had a loose surface and large openings [19-20]. 
The basic performance of trickling filters is the biological removal of organic matter. From this study, high COD removals were achieved (that reached 88 to $90 \%$ ). Low removals in EC are achieved as this treatment does not remove TDS.

4.4 Removal of other pollutants using BTF

In this phase, the optimized conditions from RSM experiments were applied in the BTF. The BTF was adapted as previously mentioned and operated continuously for 7 days. Removal of other pollutants such as $\mathrm{BOD}_{5}$, ammonia $\left(\mathrm{NH}_{3}\right)$, nitrite $\left(\mathrm{NO}_{2}\right)$, nitrate $\left(\mathrm{NO}_{3}\right)$, manganese $(\mathrm{Mn})$, phenols, total organic carbon (TOC), and oil and grease was examined during 7 days of operation. The average removal efficiencies of the pollutants in the optimized BTF are illustrated in Table 8. Commonly, more than $50 \%$ of the pollutants are removed in the BTF. Biological processes had a considerable effect on the removal of contaminants in synthetic dairy wastewater. Further primary and tertiary treatment processes are suggested to remove other pollutants $[15,17,21]$. In literature, approximately $35 \%$ of $\mathrm{BOD}_{5}$ can be removed in the primary treatment processes [15]. Thus, approximately $90 \%$ of $\mathrm{BOD}_{5}$ can be removed from wastewater.

Table 8: Average removal efficiencies for other pollutants in the BTF

\begin{tabular}{|c|c|c|}
\hline No. & Parameter & Removal efficiency $\%$ \\
\hline 1 & $\mathrm{BOD}_{5}$ & 55.36 \\
\hline 2 & $\mathrm{NH}_{3}$ & 52.83 \\
\hline 3 & $\mathrm{NO}_{2}$ & 63.29 \\
\hline 4 & $\mathrm{NO}_{3}$ & 14.28 \\
\hline 5 & $\mathrm{Mn}$ & 57.31 \\
\hline 6 & Phenols & 33.61 \\
\hline 7 & TOC & 76.51 \\
\hline 8 & Oil and grease & 53.47 \\
\hline
\end{tabular}

4.5 Application of BTF equations on the obtained data

In this research, single-stage BTF was suggested. The following equation was used (Metcalf and Eddy, 2014):

$E_{1}=\frac{100}{1+0.4432 \sqrt{\frac{W_{1}}{V F}}}$

Where

$\mathrm{E}_{1}=\mathrm{BOD}$ removal efficiency $(\%)$ for the first-stage filter is at $20^{\circ} \mathrm{C}$, including recirculation

$\mathrm{W}_{1}=\mathrm{BOD}$ loading to filter, $\mathrm{kg} / \mathrm{d}$

$\mathrm{V}=$ volume of filter packing, $\mathrm{m}^{3}$

$\mathrm{F}=$ recirculation factor and defined by:

$$
\mathrm{F}=\frac{1+\mathrm{R}}{\left(1+\frac{\mathrm{R}}{10}\right)^{2}}
$$

Where

$\mathrm{R}=$ recycle ratio, unitless

The recycle ratio is defined as the ratio of recirculation flow to the filter influent flow. Its value varies from 0 to 2 .

In the experimental work no recirculation was performed, $\mathrm{R}=0$.

Area of the BTF $=\pi * r^{2}=\pi *(0.075)^{2}=0.0176 \mathrm{~m}^{2}$

Volume (V) of BTF for $90 \mathrm{~cm}$ depth:

$\mathrm{V}=$ Area $*$ depth $=0.0176 \mathrm{~m}^{2} * 0.90 \mathrm{~m}=0.0159 \mathrm{~m}^{3}$

Flow rate of $\mathrm{BTF}=0.1 \mathrm{~L} / \mathrm{min}=144 \mathrm{~L} /$ day/one $\mathrm{BTF}$

Influent $\mathrm{BOD}_{5}$ concentration to the $\mathrm{BTF}=130 \mathrm{mg} / \mathrm{L}$

Effluent $\mathrm{BOD}_{5}$ concentration $=40 \mathrm{mg} / \mathrm{L}$

BOD5 loading to the BTF $=\frac{144 \frac{\mathrm{L}}{\mathrm{day}} * 130 \mathrm{mg} / \mathrm{L}}{(1000)^{2} \mathrm{mg} / \mathrm{kg}}=0.01872 \mathrm{~kg} \cdot \mathrm{day}=W_{1}$

$\mathrm{F}=\frac{1+0.0}{\left(1+\frac{0.0}{10}\right)^{2}}=1$

$E_{1}=\frac{100}{1+0.4432 \sqrt{\frac{0.01872}{V 0.0159 * 1}}}=67.52 \%$

The effect of wastewater temperature on BOD removal efficiency is calculated as follows:

$\mathrm{E}_{\mathrm{T}}=\mathrm{E}_{20}(1.035)^{\mathrm{T}-20}$

Where

$\mathrm{E}_{\mathrm{T}}=\mathrm{BOD}_{5}$ removal efficiency $(\%)$ at temperature $(\mathrm{T})$, and

$\mathrm{E}_{20}=\mathrm{BOD}$ removal (\%) efficiency at $20^{\circ} \mathrm{C}$

Average synthetic dairy wastewater temperature $=15^{\circ} \mathrm{C}$

$\mathrm{E}_{\mathrm{T}}=67.52(1.035)^{15-20}=56.82 \%$ 
$\mathrm{BOD}_{5}$ removal of $56.82 \%$ is very close to $\mathrm{BOD}_{5}$ removal value $(55.36 \%)$ presented in Table 8 . Biodegradability ratio for the wastewater sample is equal to $\mathrm{BOD}_{5} / \mathrm{COD}$ [17]. In the current work, the average biodegradability ratio for wastewater samples was 0.65 . It can be noticed that BTF is efficient for removal of organic matter from wastewaters with biodegradability ratio of greater than 0.5 and this is agreed with the literature $[15,17]$.

\section{CONCLUSIONS}

In this study, three types of filter media (river rock, disposed of plastic caps, and PVC pipe parts) with different sizes and various depths were studied for the treatment of synthetic dairy wastewater. An analysis of the properties of filter media revealed that a small filter media resulted in a high SSA and low void ratio. Based on the removal efficiencies for the BTFs, the disposed plastic caps of medium size $(5 \mathrm{~cm})$ with a filter depth of $60 \mathrm{~cm}$ were selected as the optimum condition. The condition had a large SSA and a sufficient void ratio for biological activity within the filter particles. The optimum values for COD, EC, turbidity, and color removal were $90.19 \%, 5.21 \%, 88.37 \%$, and $84.23 \%$, respectively.

\section{REFERENCES}

[1] Cristian, O. (2010). Characteristics of the untreated wastewater produced by food industry, Annals of University of Oradea, Fascicle: Environment, 15: 709-714.

[2] Deshannavar, U. B., Basavaraj. R. K., and Naik, N. M. (2012). High rate digestion of dairy industry effluent by upflow anaerobic fixed-bed reactor, J. of Chemical and Pharmaceutical Research, 4(6): 2895-2899.

[3] Shete, B. S., Shinkar, N. P. (2013). Dairy Industry Wastewater Sources, Characteristics \& its Effects on Environment, International J. of Current Engineering and Technology, 3(5): 1611-1615.

[4] http://www.yoruksut.com.tr/en/corporate.

[5] Alves, C. F., Melo, L.F.,and Vieira, M.J. (2002). Influence of medium composition on the characteristics of a denitrifying biofilm formed by Alcaligenes denitrificans in a fluidized bed reactor, J. of Process Biochemistry, 37: 837-845.

[6] Holá, V., Růžička, F., and Votava, M. (2006). The dynamics of staphylococcus epidermis biofilm formation in relation to nutrition, temperature, and time, J. of SCRIPTA MEDICA (BRNO), 79 (3): 169-174.

[7] Kandasamy, J., Vigneswaran, S., Hoang, T. T. L. and Chaudhary, N. S. (2009). Adsorption and Biological Filtration in Wastewater Treatment, Water and wastewater Treatment Technologies, EOLSS. Unisco publications. Available at: http://www.eolss.net/Eolss-sampleAllChapter.aspx. [Accessed on $27^{\text {th }}$ July 2016).

[8] Gulhane, M., and Charpe, A. (2015). Multimedia Filter for Domestic Wastewater Treatment, J. of Environmental Research and Development, 9(3A): 971-975.

[9] Shahriari, T., and Shokouhi, M. (2015). Assessment of Bio-Trickling Filter Startup for Treatment of Industrial Wastewater, Int. J. of Environ. Res., 9(2): 769-776.

[10] Bas, D., and Boyaci, I. H. (2007). Modeling and optimization I: Usability of response surface methodology, J. Food Eng.78: 836-845.

[11] Aziz, S.Q. (2004). Seasonal Variation of Some Physical and Chemical Properties of Water and Wastewater in Erbil City, Journal of Duhok University- Scientific and Academic, 7 (2): 76-88.

[12] Aziz, S.Q., and Ali, S. M. (2017). Characterization of Municipal and Dairy Wastewaters with 30 Quality Parameters and Potential Wastewater Treatment by Biological Trickling Filters, International Journal of Green Energy, 14 (13): $1156-1162$.

[13]Zhang, X., Li, J., Yu, Y., Xu, R., and Wu, Z. (2016). Biofilm characteristics in natural ventilation trickling filters (NVTFs) for municipal wastewater treatment: Comparison of three kinds of biofilm carriers, J. of Biochemical Engineering, 106: 8796.

[14] Lemji, H. H., and Eckstadt, H. (2013). A pilot scale trickling filter with pebble gravel as media and its performance to remove chemical oxygen demand from synthetic brewery wastewater, J. of Zhejiang University-Science B (Biomedicine \& Biotechnology), 14(10): 924-933.

[15] Metcalf and Eddy (2014). Wastewater Engineering: Treatment and Reuse, $5^{\text {th }}$ edition, Inc., Mc Graw-Hill, New York.

[16]Zinatizadeh, A. A. L., Pirsaheb, M., Bonakdari, H., and Younesi, H. (2010). Response surface analysis of effects of hydraulic retention time and influent feed concentration on performance of an UASFF bioreactor, J. of Waste Management, 30: 1798-1807.

[17] Aziz, S. Q. (2011). Landfill Leachate Treatment Using Powdered Activated Carbon Augmented SBR Process, Ph.D. Dissertation, unpublished, University Sains Malaysia.

[18]Zinatizadeh, A. A. L., Mansouri, Y., Akhbari, A., and Pashaei, S. (2011). Biological Treatment of a Synthetic Wastewater in a Sequencing Batch Biofilm Reactor: Statistical Modeling Using Optimization Using Response Surface Methodology, Chem. Industry \& Chem. Eng. Quarterly-Iran, 17(4): 485-495.

[19] Siboni, N., Lidor, M., Kramarsky-Winter, E., and Kushmaro, A. (2007). Conditioning film and initial biofilm formation on ceramics tiles in the marine environment, FEMS Microbiology Letters, 274(1): 24-29. 
[20] Thury, P., Bartha, L., Gulas, G., PITAS, V., Fazekas, B., and Karpati, A. (2012). Improvement of Biofilm Carriers for the Treatment of Automotive Industry Wastewater, Hungarian J. of Ind. and Chem., 40(1): 1-4.

[21] Mojiri, A., Aziz, H.A., Zaman, N.Q., Aziz, S.Q., and Zahed, M.A. (2014). Powdered ZELIAC augmented sequencing batch reactors (SBR) process for co-treatment of landfill leachate and domestic wastewater, Journal of Environmental Management, 139: 1-14. 